\title{
Parkinson's disease hospitalization rates and pesticide use in urban and non-urban regions of Brazil
}

\section{Hospitalizações por doença de Parkinson e uso de agrotóxicos em áreas urbanas e não urbanas do Brasil}

Aline de Souza Espindola Santos' (D), Noa Krawczyk², Christine Gibson Parks³, Carmen Froes Ildes Asmus ${ }^{1}$, Volney de Magalhães Câmara' ${ }^{1}$, Jaime Lima ${ }^{4}$, Armando Meyer ${ }^{1}$ (D)

'Instituto de Estudos em Saúde Coletiva, Universidade Federal do Rio de Janeiro (UFRJ) - Rio de Janeiro (RJ), Brasil. ${ }^{2}$ Drug Dependence Epidemiology Training Program, Johns Hopkins Bloomberg School of Public Health - Baltimore (MD), USA. ${ }^{3}$ Occupational and Environmental Health Branch, Public Health Institute, Epidemiology Branch, National Institute of Environmental Health Sciences (NIEHS) - Research Triangle Park (NC), USA.

${ }^{4}$ Departamento de Bioquímica, Universidade Federal do Estado do Rio de Janeiro (UNIRIO) - Rio de Janeiro (RJ), Brasil.

How to cite: Santos ASE, Krawczyk N, Parks CG, Asmus CFI, Câmara VM, Lima J, Meyer A. Parkinson's disease hospitalization rates and pesticide use in urban and non-urban regions of Brazil. Cad Saúde Colet, 2021;29(4):496-508. https://doi. org/10.1590/1414-462X202129040236

\begin{abstract}
Background: Few studies have evaluated the role played by pesticide exposure in the development of Parkinson's disease (PD) in Brazil. Objective: This study aimed to investigate the association between pesticide use and PD hospitalization in Brazilian micro-regions. Method: Pesticide expenditure per capita in 1985 and PD hospitalization rates (HR) from 1997 to 2007 were calculated for all 552 Brazilian micro-regions. The Spearman's correlation test was used to compare pesticide expenditure and PD HR by sex, age, and urban and non-urban micro-regions. Micro-regions were grouped according to the quintiles of pesticide expenditure. PD HR ratios (HRR) were calculated to compare PD HR across the quintiles of pesticide expenditure. Results: Moderate correlation $(r=0.518 ; p<0.001)$ between PD HR in non-urban micro-regions and pesticide expenditure was observed. In non-urban areas, compared with micro-regions of the first quintile of pesticide use, PD HRR ranged from 1.70 to 5.90 in micro-regions of higher pesticide use. In general, regardless of sex and age, the higher the use of pesticides, the greater the magnitude of PD HRR. Conclusion: Our results suggest that pesticide use is associated with PD in Brazil, especially in non-urban areas where pesticides are used more intensively.
\end{abstract}

Keywords: pesticides; Parkinson's disease; environmental health; hospitalizations; Brazil

\section{Resumo}

Introdução: Poucos estudos avaliaram os efeitos da exposição a agrotóxicos sobre a doença de Parkinson (DP) no Brasil. Objetivo: Este estudo teve por objetivo investigar essa associação em microrregiões brasileiras. Método: As taxas de hospitalização (TH) por DP de 1997 a 2007 e os gastos per capita com agrotóxicos em 1985 foram calculados para todas as 552 microrregiões brasileiras. O coeficiente de correlação de Spearman foi utilizado para verificar relação entre as variáveis. Foi calculada a razão de TH (RTH) por DP entre quintis de gastos com agrotóxicos em microrregiões urbanas e não urbanas, usando o $1^{\circ}$ quintil como referência. Resultados: Uma moderada correlação $(r=0,518 ; p<0,001)$ foi observada entre as TH por DP em microrregiões não urbanas e gastos com agrotóxicos. As associações entre gastos com agrotóxicos e RTH por PD foram maiores nas microrregiões não urbanas. Comparadas às microrregiões

Study carried out at Instituto de Estudos em Saúde Coletiva, Universidade Federal do Rio de Janeiro (UFRJ) - Rio de Janeiro (RJ), Brasil.

Correspondence: Armando Meyer. E-mail: armando@iesc.ufrj.br

Financial support: none.

Conflict of interests: nothing to declare.

Received on: June 28, 2019. Accepted on: Aug. 10, 2020
This is an Open Access article distributed under the terms of the Creative Commons Attribution License, which permits unrestricted use, distribution, and reproduction in any medium, provided the original work is properly cited. 
do $1^{\circ}$ quintil, as TH por DP foram de 1,70 a 5,90 vezes maiores nas demais microrregiões. Foi observada uma relação dose-reposta entre as TH por PD e os quintis de uso de agrotóxicos, independentemente de sexo e idade. Conclusão: Nossos resultados sugerem que o uso de agrotóxicos pode estar associado à DP no Brasil, especialmente em áreas não urbanas, onde o uso é mais intenso.

Palavras-chave: agrotóxicos; doença de Parkinson; saúde ambiental; hospitalizações; Brasil

\section{INTRODUCTION}

Parkinson's disease (PD) is a chronic neurodegenerative disorder'. The common motor symptoms of PD, such as bradykinesia, tremor, rigidity and postural instability, are related to the degeneration of dopaminergic neurons in the nigrostriatal pathway in the midbrain². PD incidence in the United States (US) and European countries ranges from 8/100,000 to $18 / 100,000^{3}$. Sex differences have also been observed in Western populations, where PD incidence is higher among males ${ }^{4}$. There is no data on PD incidence in Brazil, but the estimated prevalence is around 3\%, which is higher than that observed in the US, Europe, and Asia $(108 / 100,000 \text { to } 1600 / 100,000)^{5-7}$.

According to the World Health Organization $(\mathrm{WHO})^{8}$, PD and other neurodegenerative diseases together may surpass cancer and become the second most common cause of death by 2040 . Aging is an important risk factor for PD, and the incidence of this disease gradually increases in older age group $s^{8-10}$. Brazil has been experiencing a demographic transition, with declining fertility and birth rates and fast population aging ${ }^{11}$, which is expected to increase the number of PD cases and their costs to the public health system ${ }^{12,13}$.

Lifestyle, aging, and environmental factors are associated with the increasing trend of PD incidence ${ }^{14-17}$. Two meta-analyses have supported the positive association between occupational exposure to different pesticide classes and PD ${ }^{18,19}$. Evidence of the association between specific pesticides and PD is limited to the herbicide paraquat, the insecticide rotenone, and the fungicide mane $b^{19,20}$. Regarding environmental exposure to pesticides, a recent meta-analysis found a positive association between rural living, farming activities, and well-water consumption and PD21.

The use of pesticides in Brazil has substantially increased in the past two decades, with a growth rate of $163 \%$ in the 1990 s, followed by an increase of $190 \%$ in the $2000 \mathrm{~s}^{22-24}$. This increase led Brazil to the first position of pesticide use in the world in 2009 22,23 . The use of pesticides at such high levels and without proper training has raised concerns about the long-term health effects on Brazilian agricultural workers and exposed communities. Several studies have investigated the association of pesticides with health outcomes among Brazilian agricultural workers, including cancer and reproductive and mood disorders ${ }^{25-27}$. However, research on pesticides and PD in Brazil is limited to small retrospective studies ${ }^{28-30}$. In this study, we aimed to expand the literature on this theme by investigating the association between pesticide expenditures and PD hospitalization rates (HR) across a national sample of urban and nonurban regions in Brazil.

\section{METHOD}

\section{Study design}

We carried out an ecological study using data from the 1985 per capita expenditure on pesticides in each Brazilian micro-region as surrogate measures of population exposure to these toxins. Expenditure data were compared to PD HR in the same micro-regions between 1997 and 2007. We used the 1985 per capita expenditure on pesticides as a surrogate measure of population exposure to pesticides and the PD HR between 1997 and 2007 to guarantee the temporal sequence between exposure and effects. The Brazilian Institute of Geography and Statistics (IBGE) defines micro-regions as groups of adjacent municipalities that have similar socioeconomic characteristics. We conducted separate analyses for 52 urban and 500 non-urban micro-regions. Urban status was based on the IBGE definition. 


\section{Pesticide expenditure data}

Data on pesticide expenditure in each Brazilian farm were obtained from the Agricultural Census of 1985. Farm pesticide expenditures were then pooled within each micro-region and converted to US dollars (USD) based on the average currency conversion rate in July 1985. The total pesticide expenditure, in USD, for each micro-region was then divided by the number of inhabitants in the same year to obtain the per capita expenditure on pesticides for each micro-region. The use of the 1985 Agricultural Census data on pesticide expenditure relies on the fact that PD is a chronic illness with a long latency period, and the environmental exposures that may increase the risk of PD can occur decades before the onset of signs and symptoms. Thus, to investigate the association of pesticide use with PD HR in Brazil between 1997 and 2007, data on pesticide use available in the 1985 Agricultural Census were used to calculate the microregions' per capita pesticide expenditures. This allowed us to observe a difference of at least 10 years between exposure (1985) and outcome (1997-2007). Although there are three more recent Brazilian agricultural censuses, pesticide use data from two of them (2006 and 2017) could not have been used because exposure would have occurred after the disease outcome (1997-2007 PD HR), and data from the 1996 census would not have allowed observation of the long latency period of PD.

\section{Hospitalization data}

Hospital admissions due to PD (ICD-10: G20) that occurred between 01 January 1997 and 31 December 2007 among individuals aged $\geq 20$ years were retrieved from the Brazilian Hospital Information System for each micro-region. PD HR were calculated using the total number of hospital admissions between 1997 and 2007 divided by the mid-interval population (2002), multiplied by 100,000 for each micro-region. PD HR were stratified by age (20-49, 50-69, and $\geq 70$ ) and sex. The hospitalization data used in the present study are publicly available through the Brazilian Public Health System Information Technology (IT) Department ${ }^{31}$ and, therefore, did not require Institutional Review Board (IRB) review.

\section{Hospitalization rate ratios (HRR)}

The Spearman's rank correlation coefficient between per capita pesticide expenditure and HR was calculated for each age and sex stratum. All micro-regions (separated into urban and non-urban) were grouped based on the quintiles of per capita pesticide expenditure, and HR were calculated for each quintile. The HRR were then obtained by dividing the HR of each quintile by the HR of the first quintile, which was used as the reference group. The HRR and their $95 \%$ confidence intervals $(95 \% \mathrm{Cl})$ were stratified by age and sex.

\section{RESULTS}

Table 1 provides a description of the per capita expenditure on pesticides in Brazilian urban and non-urban micro-regions in 1985 and the Spearman's rank correlation coefficients between per capita pesticide expenditures and PD HR according to age and sex. Per capita pesticide expenditure was 4 times higher in non-urban than in urban micro-regions. Correlation coefficients between per capita pesticide expenditure and PD HR were highest for non-urban $(r=0.518)$ and lowest in urban $(r=0.372)$ micro-regions. When the analysis was restricted to non-urban micro-regions, older groups showed higher correlation coefficients $(r=0.485)$, though no differences were observed according to sex.

Table 2 presents the HRR for PD stratified by age and micro-region status to the population using pesticide expenditure data from 1985. Overall, for all ages, in urban and non-urban micro-regions, quintiles with higher pesticide expenditure presented higher PD HR than the reference quintile. However, in urban micro-regions, the highest HRR was observed in the 4th quintile. Non-urban micro-regions exhibited the highest PD HRR in all quintiles compared with urban micro-regions, with a consistent rise in PD HRR as quintiles increase in per capita pesticide expenditure. In the edge age groups (20-49 and $\geq 70)$, a significant difference in PD 
Table 1. Correlation between pesticide expenditure per capita in Brazilian micro-regions in 1985 and PD hospitalization rates from 1997 to 2007

\begin{tabular}{|c|c|c|c|}
\hline & $\begin{array}{c}\text { Urban } \\
\text { micro-regions } \\
(52)\end{array}$ & $\begin{array}{c}\text { Non-urban } \\
\text { micro-regions } \\
(500)\end{array}$ & $\begin{array}{c}\text { All } \\
\text { micro-regions } \\
(552)\end{array}$ \\
\hline Year & & 1985 & \\
\hline Population & $54,747,410$ & $76,891,862$ & $131,639,272$ \\
\hline Sales (USD) & $190,972.27$ & $1,182,961.47$ & $1,373,933.74$ \\
\hline $\begin{array}{l}\text { Per capita expenditure on } \\
\text { pesticides }\end{array}$ & 0.003 & 0.012 & 0.008 \\
\hline $\begin{array}{l}\text { Spearman's rank } \\
\text { correlation coefficient }\end{array}$ & $\mathbf{N}$ & $\mathbf{r}$ & $p$ \\
\hline All micro-regions & 552 & 0.496 & $<0.001$ \\
\hline Urban micro-regions & 52 & 0.372 & 0.007 \\
\hline Non-urban micro-regions & 500 & 0.518 & $<0.001$ \\
\hline \multicolumn{4}{|l|}{$\begin{array}{l}\text { Non-urban micro-regions } \\
\text { by age }\end{array}$} \\
\hline $20-49$ years & 500 & 0.368 & $<0.001$ \\
\hline $50-69$ years & 500 & 0.425 & $<0.001$ \\
\hline$\geq 70$ years & 500 & 0.485 & $<0.001$ \\
\hline \multicolumn{4}{|l|}{$\begin{array}{l}\text { Non-urban micro-regions } \\
\text { by sex }\end{array}$} \\
\hline Men & 500 & 0.500 & $<0.001$ \\
\hline Women & 500 & 0.479 & $<0.001$ \\
\hline
\end{tabular}

HRR could already be observed by the 3rd quintile, which has a PD HRR over two times that of micro-regions in the lowest quintile. By the 5th quintile, the HRR for PD were up to 4 to 6 times higher.

The HRR for PD stratified by age and micro-region status to male according to 1985 pesticide expenditure quintiles are presented in Table 3. In the urban micro-regions, males showed higher PD HRR in the 4th quintile compared with the 5th quintile, especially for the edge age groups ( $20-49$ and $\geq 70$ ). Differences in the magnitude of PD HRR for males between urban and non-urban micro-regions were observed for all quintiles analyzed, with PD HRR being the highest in non-urban micro-regions. Non-urban micro-regions showed a gradual shift towards higher PD HRR with increasing pesticide expenditure. Edge age groups showed the highest PD HRR in the top quintiles, in particular in the 5th quintile, where the increase was five times higher than in the 1st quintile.

When the PD HRR for females was stratified by age in urban micro-regions, an increased PD HRR was observed in the 4th quintile compared with the 1st quintile, mainly for the 5069 and $\geq 70$ age groups. In the 5th quintile for females, the PD HRR was lower than that in the 4 th quintile. Non-urban regions showed a dose-response-like pattern with an increase in the PD HRR across pesticide expenditure quintiles compared with the reference quintile. By the 5th quintile, the PD HRR were up to 5 to 7 times that of micro-regions in the reference quintile. (Table 4). 


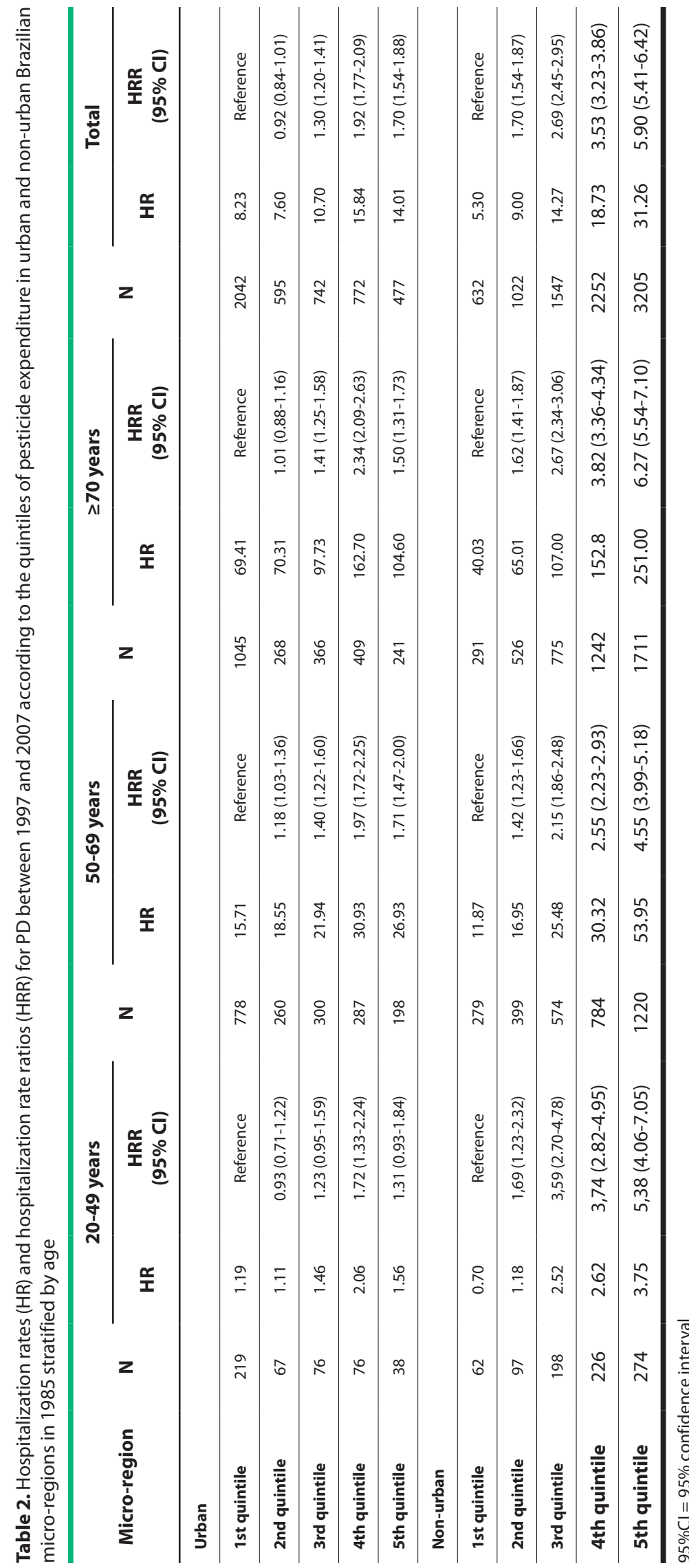




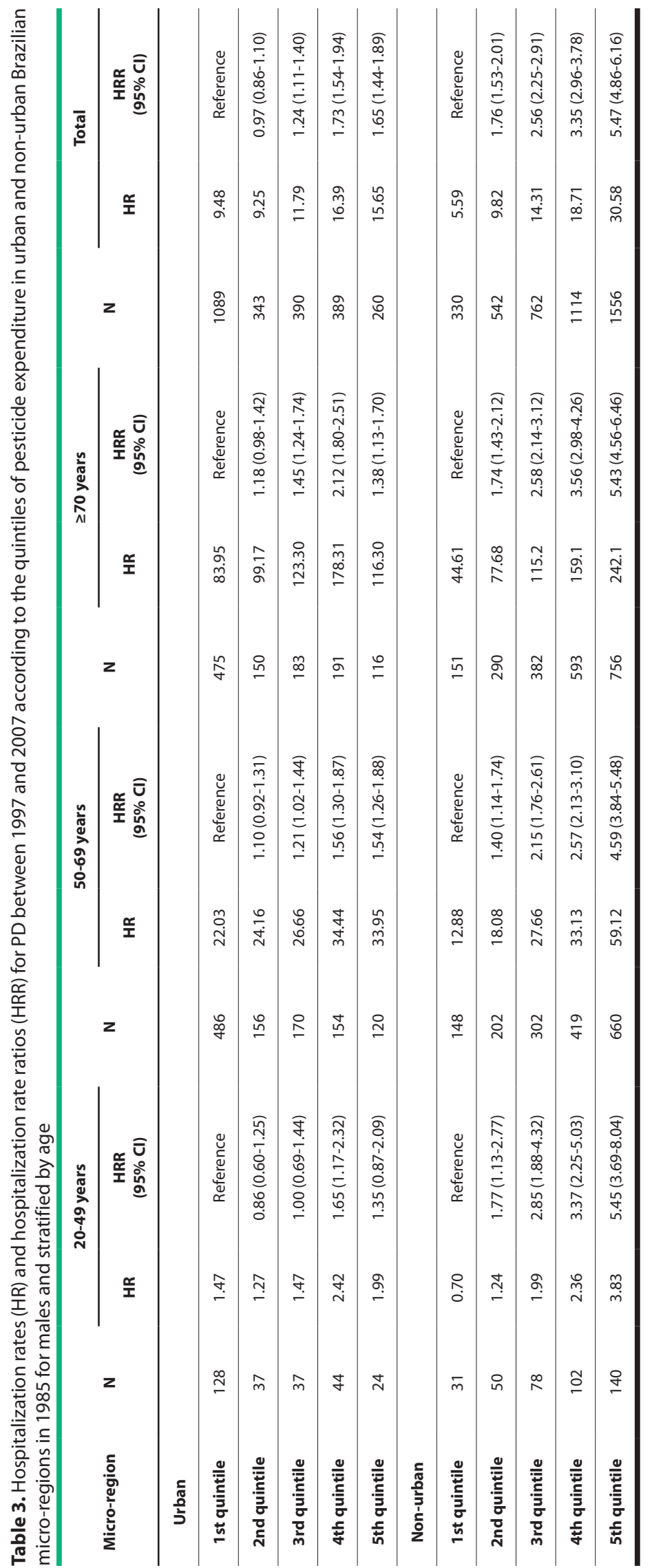




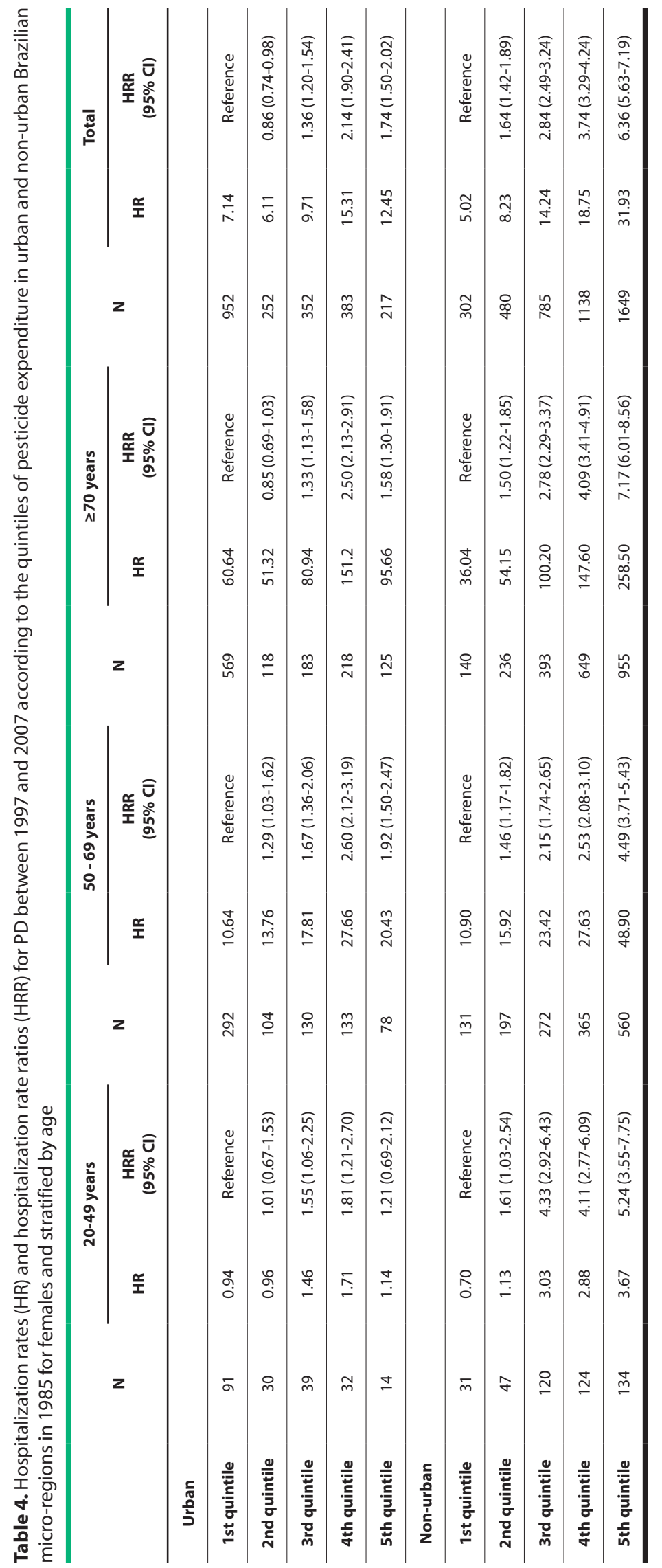




\section{DISCUSSION}

Our study showed an association between per capita pesticide expenditure and HR for PD in Brazil. The correlation between pesticide expenditure and PD HR was highest in nonurban micro-regions, and the regions with higher pesticide expenditures experienced higher PD HR with a pronounced increasing gradient of $\mathrm{HR}$ with increasing pesticide expenditure in non-urban micro-regions. Although we were not able to evaluate direct exposure to pesticides in hospitalized individuals, people living in regions with heavier pesticide consumption may experience higher environmental or occupational exposure. Therefore, these results also corroborate findings of other studies that observed positive associations between environmental or occupational pesticide exposure and $\mathrm{PD}^{32,33}$.

A meta-analysis found a summary risk ratio (sRR) of 1.62 (95\% Cl=1.40-1.88) for PD in case-control, cohort, and cross-sectional studies assessing occupational and non-occupational exposure to pesticides. In addition, studies based on job-title exposure have reported higher risks estimates ( $\mathrm{RR}=2.5 ; 95 \% \mathrm{Cl}=1.50-4.10)$ than studies based on self-reported exposure $(\mathrm{RR}=1.5 ; 95 \% \mathrm{Cl}=1.30-1.80)^{34}$. Increased risk of PD has also been associated with exposure to the insecticides chlorpyrifos and rotenone, the fungicides maneb and mancozeb, and the herbicide paraquat in the states of Texas and California, USA ${ }^{35-37}$. Some studies also have suggested possible associations of PD risk with exposure to hexachlorocyclohexane ${ }^{38,39}$. In Brazil, the use of these pesticides has been reported since the 1960s, but it was not possible to estimate the amount used in the micro-regions assessed in 1985 40-43.

Our results also suggest that, in non-urban micro-regions, PD was associated with pesticide expenditure even in the lower age groups. Whereas a diagnostic code for PD suggests a clinical judgment, misdiagnosis of early PD onset sometimes occurs due to the absence of some classic PD symptoms found in older individuals ${ }^{44}$. While PD affects mostly people over the age of $60^{45}$, positive correlations between pesticide exposure and early PD onset have previously been observed ${ }^{46,47}$. Our results support these findings and suggest that early PD and pesticide exposure be further investigated.

Our analyses of urban micro-regions showed that PD HR, in general, rose in the quintiles with higher pesticide expenditure, but they dropped in the last quintiles, which showed the highest pesticide expenditure. This unexpected drop in the magnitude of the HRR observed for the 5th quintiles may reflect differences in the distribution of other risk factors for PD not evaluated in this study, including exposure to solvents, head traumas, air pollution ${ }^{48-51}$, and several other possible confounders related to the distribution and grouping strategies of Brazilian municipalities into urban micro-regions.

Brazilian cities with high industrial activities and human development indexes (HDI) are often defined as urban even when they present high levels of agricultural activity. Moreover, pesticides are also heavily used in urban areas of Brazil to control vector-borne diseases such as dengue, malaria, leishmaniasis, and Chagas disease ${ }^{52,53}$. As pesticides play an important role in pest control and even in regular gardening activities in urban areas, they should also be considered as a possible risk factor for some pesticide-related diseases, such as PD, in these areas $^{54}$. Some studies have suggested positive associations between PD and exposure to the insecticides malathion and hexachlorocyclohexane ${ }^{38,55}$. The Brazilian vector control program in the 1980s and 90s indicated the use of these specific insecticides for the control of dengue and malaria mosquitoes ${ }^{56-58}$.

Hospitalizations may be influenced by the disease prevalence (PD prevalence is higher in males), access to health care and treatment, disease severity, comorbidities, and socioeconomic and cultural disparities ${ }^{59}$. Sex differences in PD HR were partially observed in our study. In urban areas, men consistently had higher PD HR compared with women in all quintiles of pesticide use. Accordingly, men also showed higher PD HR in non-urban areas compared with women, but less consistently. These results might be related to the lack of adjustment for variables associated with HR such as disease severity, comorbidities and socioeconomic and cultural disparities that affect men and women differentially ${ }^{60-62}$.

Brazilian rural areas have a significant dependence on public health facilities, insufficient number of health professionals, and weak health infrastructure. Thus, differences in medical 
assistance between urban and non-urban micro-regions may have an impact on PD HR. However, we believe that this difference in access to health services may not have had an influence on the association between PD and pesticide exposure, as we do not believe that access to health care would have changed across the quintiles of pesticide use in Brazil.

It is important to stress that there is no consensus on the association between pesticide exposure and PD in the literature, although most of the evidence points to that direction ${ }^{21}$. Measurement of population exposure is crucial to precisely estimate the magnitude of the association between PD and pesticide use $\mathrm{e}^{32}$. In our study, the lack of information regarding specific classes and types of pesticides used (insecticides, herbicides, fungicides, etc.) did not allow us to perform a more detailed analysis of the relationship between specific pesticides and PD. Despite this limitation, the different types of crops found in each studied quintile of pesticide expenditure suggest differences in the types of pesticides used among them. In 1985, in terms of planted area in the five studied quintiles, rice, corn, and coffee were always among the five most common crops, regardless of the quintile. In addition, soybean was also among the most common crops in four of these quintiles ( $2 \mathrm{nd}, 3 \mathrm{rd}, 4$ th, and 5 th). Cassava, sugar cane, and beans were the fifth most common crop depending on the specific quintile. On the other hand, recent reports from the Brazilian Institute of Environmental and Renewable Natural Resources (IBAMA) show small variations in the five most commonly sold pesticides in the five Brazilian regions between 2009 and $2018^{63}$. Comparing these two years, glyphosate and 2,4-D were among the five most commonly commercialized pesticides in all Brazilian regions in both 2009 and 2018. The third most common pesticide used in all Brazilian regions in 2009 was the herbicide atrazine, while in 2018, the fungicide mancozeb took its place. The fourth and fifth most used pesticides varied in each of the Brazilian regions and the two compared years. In 2009, these places were taken by the fungicides carbendazim, sulfur, copper, mancozeb and thiophanate-methyl, the herbicide picloram, and the insecticides malathion and methamidophos. On the other hand, in 2018, the fungicides sulfur and copper, the herbicides picloram, paraquat, triclopyr-butotyl, and atrazine, and the insecticides acephate and malathion took these positions.

The nature of this ecological analysis imposes some limitations to our results, as the associations observed at the micro-region level may not reflect the true individual relationship of exposure to pesticides and PD. Another limitation to this study is that we were unable to verify whether expenditure on pesticides in a micro-region correlates with pesticide use in that micro-region, as pesticides may be purchased in a certain region, due to a more competitive price, but actually be used in another. In addition, there is no data on specific pesticides used in each Brazilian municipality. Data on specific crops cultivated in Brazilian municipality could be used as a proxy to estimate pesticide use in Brazil. However, considering the 552 micro-regions that comprise the 5,570 municipalities in Brazil, it would have been challenging to describe the types of crops cultivated in each of these micro-regions. Furthermore, due to difficulty in determining PD diagnosis ${ }^{64}$, misdiagnosis may lead to underestimation of HR.

Despite these limitations, the use of a large database in this study has enabled a robust evaluation of the data. To ensure that exposure to these pesticides would have occurred before PD development, diagnosis, and hospitalization, we used data on per capita pesticide expenditure in 1985. Data on pesticide use in each Brazilian municipality are provided by the Brazilian agricultural censuses. In that sense, there are four of these censuses with pesticide use data so far: $1985,1996,2006$, and 2017 . It is our best understanding that to ensure temporality between exposure and outcome, the 1985 pesticide use data are more appropriate than those of the other censuses. In addition, although we agree that there has been an exponential growth in pesticide use in Brazil, the variation in per capita pesticide expenditure across Brazilian municipalities, and consequently micro-regions, has not change significantly over time, which is confirmed by the high correlation between per capita pesticide expenditures in Brazil in 1985, 1996, and 2006 (data not shown). Finally, since the mid-1990s, the amount and types of pesticides used in Brazil have increased dramatically ${ }^{24}$. The use of glyphosate, for instance, has increased exponentially since the 2000s. In fact, Brazil has become one of the top consumers of this chemical in the world ${ }^{65,66}$. Since environmental exposure may occur decades 
before the onset of PD signs and symptoms, the effect of pesticide consumption in more recent years may play a role in the development of PD and, therefore, in PD HR, in the coming years.

The results of this study corroborate the hypothesis that the use of pesticides may be associated with an increased risk of PD. The findings also suggest that the relationship between pesticide consumption and PD HR is higher and more gradual in non-urban micro-regions. Pesticide use in Brazil is a significant public health concern due to its potential long-term effects of environmental and occupational exposure. Our results support that there is a relationship between PD, a chronic neurodegenerative disease, and pesticide exposure; however, further high-quality studies are required prove this association.

\section{REFERENCES}

1. Shulman JM, De Jager PL, Feany MB. Parkinson's disease: genetics and pathogenesis. Annu Rev Pathol. 2011;6(1):193-222. http://dx.doi.org/10.1146/annurev-pathol-011110-130242. PMid:21034221.

2. Dexter DT, Jenner P. Parkinson disease: from pathology to molecular disease mechanisms. Free Radic Biol Med. 2013;62:132-44. http://dx.doi.org/10.1016/j.freeradbiomed.2013.01.018. PMid:23380027.

3. Twelves D, Perkins KS, Counsell C. Systematic review of incidence studies of Parkinson's disease. Mov Disord. 2003;18(1):19-31. http://dx.doi.org/10.1002/mds.10305. PMid:12518297.

4. Taylor KS, Cook JA, Counsell CE. Heterogeneity in male to female risk for Parkinson's disease. J Neurol Neurosurg Psychiatry. 2007;78(8):905-6. http://dx.doi.org/10.1136/jnnp.2006.104695. PMid:17635983.

5. Barbosa MT, Caramelli P, Maia DP, Cunningham MC, Guerra HL, Lima-Costa MF, et al. Parkinsonism and Parkinson's disease in the elderly: A community-based survey in Brazil (the Bambuí study). Mov Disord. 2006;21(6):800-8. http://dx.doi.org/10.1002/mds.20806. PMid:16482566.

6. von Campenhausen S, Bornschein B, Wick R, Bötzel K, Sampaio C, Poewe W, et al. Prevalence and incidence of Parkinson's disease in Europe. Eur Neuropsychopharmacol. 2005;15(4):473-90. http://dx.doi. org/10.1016/j.euroneuro.2005.04.007. PMid:15963700.

7. Willis AW, Evanoff BA, Lian M, Criswell SR, Racette BA. Geographic and ethnic variation in Parkinson disease: a population-based study of US Medicare beneficiaries. Neuroepidemiology. 2010;34(3):143-51. http:// dx.doi.org/10.1159/000275491. PMid:20090375.

8. Reeve A, Simcox E, Turnbull D. Ageing and Parkinson's disease: Why is advancing age the biggest risk factor? Ageing Res Rev. 2014;14:19-30. http://dx.doi.org/10.1016/j.arr.2014.01.004. PMid:24503004.

9. Pringsheim T, Jette N, Frolkis A, Steeves TD. The prevalence of Parkinson's disease: a systematic review and meta-analysis. Mov Disord. 2014;29(13):1583-90. http://dx.doi.org/10.1002/mds.25945. PMid:24976103.

10. World Health Organization. Neurology atlas: brief review of selected topics [Internet]. Geneva:WHO; 2004 [cited 2013 Sept 15]. Available from: http://www.who.int/mental_health/neurology/neurogy_atlas_Ir.pdf

11. Bovolenta TM, Felicio AC. How do demographic transitions and public health policies affect patients with Parkinson's disease in Brazil? Clin Interv Aging. 2017;12:197-205. http://dx.doi.org/10.2147/CIA.S123029. PMid:28182156.

12. Dorsey E, Constantinescu R, Thompson JP, Biglan KM, Holloway RG, Kieburtz K, et al. Projected number of people with Parkinson disease in the most populous nations, 2005 through 2030. Neurology. 2007;68(5):384-6. http://dx.doi.org/10.1212/01.wnl.0000247740.47667.03. PMid:17082464.

13. Bovolenta TM, Felício AC. Parkinson's patients in the Brazilian Public Health Policy context. Einstein. 2016;14(3):7-9. http://dx.doi.org/10.1590/S1679-45082016ED3780. PMid:27759839.

14. Savica R, Grossardt BR, Bower JH, Ahlskog JE, Rocca WA. Time trends in the incidence of Parkinson disease. JAMA Neurol. 2016;73(8):981-9. http://dx.doi.org/10.1001/jamaneurol.2016.0947. PMid:27323276.

15. Di Monte DA. The environment and Parkinson's disease: is the nigrostriatal system preferentially targeted by neurotoxins? Lancet Neurol. 2003;2(9):531-8. http://dx.doi.org/10.1016/S1474-4422(03)00501-5. PMid:12941575.

16. Warner TT, Schapira AH. Genetic and environmental factors in the cause of Parkinson's disease. Ann Neurol. 2003;53(Suppl. 3):S16-23. http://dx.doi.org/10.1002/ana.10487. PMid:12666095.

17. Goldman SM. Environmental toxins and Parkinson's disease. Annu Rev Pharmacol Toxicol. 2014;54(1):14164. http://dx.doi.org/10.1146/annurev-pharmtox-011613-135937. PMid:24050700.

18. Van Maele-Fabry G, Hoet P, Vilain F, Lison D. Occupational exposure to pesticides and Parkinson's disease: a systematic review and meta-analysis of cohort studies. Environ Int. 2012;46:30-43. http://dx.doi. org/10.1016/j.envint.2012.05.004. PMid:22698719. 
19. Brown TP, Rumsby PC, Capleton AC, Rushton L, Levy LS. Pesticides and Parkinson's disease: is there a link? Environ Health Perspect. 2006;114(2):156-64. http://dx.doi.org/10.1289/ehp.8095. PMid:16451848.

20. Brouwer M, Huss A, van der Mark M, Nijssen PC, Mulleners WM, Sas AM, et al. Environmental exposure to pesticides and the risk of Parkinson's disease in the Netherlands. Environ Int. 2017;107:100-10. http:// dx.doi.org/10.1016/j.envint.2017.07.001. PMid:28704700.

21. Breckenridge CB, Berry C, Chang ET, Sielken RL Jr, Mandel JS. Association between Parkinson's disease and cigarette smoking, rural living, well-water consumption, farming and pesticide use: systematic review and meta-analysis. PLoS One. 2016;11(4):e0151841. http://dx.doi.org/10.1371/journal.pone.0151841. PMid:27055126.

22. Brasil. Agência Nacional de Vigilância Sanitária. Seminário de mercado de agrotóxico e regulação [Internet]. Brasília; 2012 [cited 2013 Sept 15]. Available from: http://portal.anvisa.gov.br/resultadode-busca?p_p_id=101\&p_p_lifecycle $=0 \& p \_p \_s t a t e=$ maximized $\&$ p_p_mode $=v i e w \& p \_p \_c o l \_$ id=column1\&p_p_col_count=1\&_101_struts_action=\%2Fasset_publisher\%2Fview_content \&_101_ assetEntryld=2665456\&_101_type=content $\&$ 101_groupld=219201\&_101_urlTitle=seminario-voltaa-discutir-mercado-de-agrotoxicos-em-2012\&inheritRedirect=true

23. Ferreira MJM, Viana MM Jr. A expansão do agronegócio no semiárido cearense e suas implicações para a saúde, o trabalho e o ambiente. Interface. 2016;20(58):649-60. http://dx.doi.org/10.1590/180757622015.0029.

24. Campanhola C, Bettiol W. Panorama sobre o uso de agrotóxicos no Brasil. In: Campanhola C, Bettiol W, editors. Métodos alternativos de controle fitossanitário. Jaguariúna: Embrapa Meio Ambiente; 2003.

25. Cremonese C, Freire C, Camargo AM, De Lima JS, Koifman S, Meyer A. Pesticide consumption, central nervous system and cardiovascular congenital malformations in the South and Southeast region of Brazil. Int J Occup Med Environ Health. 2014;27(3):474-86. http://dx.doi.org/10.2478/s13382-014-0269-5. PMid:24847732.

26. Meyer A, Alexandre PC, Chrisman JR, Markowitz SB, Koifman RJ, Koifman S. Esophageal cancer among Brazilian agricultural workers: case-control study based on death certificates. Int J Hyg Environ Health. 2011;214(2):151-5. http://dx.doi.org/10.1016/j.ijheh.2010.11.002. PMid:21159552.

27. Meyer A, Koifman S, Koifman RJ, Moreira JC, Chrisman JR, Abreu-Villaca Y. Mood disorders hospitalizations, suicide attempts, and suicide mortality among agricultural workers and residents in an area with intensive use of pesticides in Brazil. J Toxicol Environ Health A. 2010;73(13-14):866-77. http://dx.doi. org/10.1080/15287391003744781. PMid:20563920.

28. Carvalho AP, Lessa PS, Godeiro C Jr, Barsottini O, Felício AC, Borges V, et al. Genetic and environmental findings in early-onset Parkinson's disease Brazilian patients. Mov Disord. 2008;23(9):1228-33. http:// dx.doi.org/10.1002/mds.22032. PMid:18464276.

29. Werneck ALS, Alvarenga H. Genetics, drugs and environmental factors in Parkinson's disease: a case-control study. Arq Neuropsiquiatr. 1999;57(2B):347-55. http://dx.doi.org/10.1590/S0004-282X1999000300001. PMid:10450337.

30. Godeiro C Jr, Aguiar PM, Felı'cio AC, Barsottini OG, Silva SM, Borges V, et al. PINK1 polymorphism IVS1-7 A(G, exposure to environmental risk factors and anticipation of disease onset in Brazilian patients with earlyonset Parkinson's Disease. Neurosci Lett. 2010;469(1):155-8. http://dx.doi.org/10.1016/j.neulet.2009.11.064. PMid:19944740.

31. Brasil. Ministério da Saúde. DATASUS [Internet]. Brasília; 2013 [cited 2013 Sept 15]. Available from: http:// datasus.saude.gov.br/

32. Narayan S, Liew Z, Paul K, Lee PC, Sinsheimer JS, Bronstein JM, et al. Household organophosphorus pesticide use and Parkinson's disease. Int J Epidemiol. 2013;42(5):1476-85. http://dx.doi.org/10.1093/ije/ dyt170. PMid:24057998.

33. Hristina VD, Sipetic SB, Maksimovic JM, Marinkovic JM, Dzoljic ED, Ratkov IS, et al. Environmental factors and Parkinson's disease: a case-control study in Belgrade, Serbia. Int J Neurosci. 2010;120(5):361-7. http:// dx.doi.org/10.3109/00207451003668374. PMid:20402575.

34. van der Mark M, Brouwer M, Kromhout H, Nijssen P, Huss A, Vermeulen R. Is pesticide use related to Parkinson disease? Some clues to heterogeneity in study results. Environ Health Perspect. 2012;120(3):3407. http://dx.doi.org/10.1289/ehp.1103881. PMid:22389202.

35. Dhillon AS, Tarbutton GL, Levin JL, Plotkin GM, Lowry LK, Nalbone JT, et al. Pesticide/environmental exposures and Parkinson's disease in east Texas. J Agromed. 2008;13(1):37-48. http://dx.doi. org/10.1080/10599240801986215. PMid:19042691. 
36. Wang A, Costello S, Cockburn M, Zhang X, Bronstein J, Ritz B. Parkinson's disease risk from ambient exposure to pesticides. Eur J Epidemiol. 2011;26(7):547-55. http://dx.doi.org/10.1007/s10654-011-9574-5. PMid:21505849.

37. Costello S, Cockburn M, Bronstein J, Zhang X, Ritz B. Parkinson's disease and residential exposure to maneb and paraquat from agricultural applications in the central valley of California. Am J Epidemiol. 2009;169(8):919-26. http://dx.doi.org/10.1093/aje/kwp006. PMid:19270050.

38. Richardson JR, Shalat SL, Buckley B, Winnik B, O'Suilleabhain P, Diaz-Arrastia R, et al. Elevated serum pesticide levels and risk of Parkinson disease. Arch Neurol. 2009;66(7):870-5. http://dx.doi.org/10.1001/ archneurol.2009.89. PMid:19597089.

39. Richardson JR, Roy A, Shalat SL, Buckley B, Winnik B, Gearing M, et al. Beta Hexachlorocyclohexane levels in serum and risk of Parkinson's disease. Neurotoxicology. 2011;32(5):640-5. http://dx.doi.org/10.1016/j. neuro.2011.04.002. PMid:21620887.

40. Ferreira TPRRC, Carvalho CF. O setor de defensivos agrícolas no Brasil: evolução e tendências [Internet]. São Paulo: Instituto de Economia Agrícola; 1985 [cited 2013 Sept 15]. Available from: http://www.iea. sp.gov.br/out/verTexto.php?codTexto=9834

41. Ferreira TPRRC, Carvalho CF, Carmo BJA. Evolução do setor de defensivos agrícolas no Brasil, 1964-83 [Internet]. São Paulo: Instituto de Economia Agrícola; 1986. Relatório de Pesquisa [cited 2013 Sept 15]. Available from: http://www.iea.sp.gov.br/out/TerTexto.php?codTexto=10625

42. Banco Nacional do Desenvolvimento Econômico. Defensivos para a agricultura. Rev BNDE [Internet]. 1968;5(1):70-82 [cited 2013 Sept 15]. Available from: https://web.bndes.gov.br/bib/jspui/ handle/1408/12174

43. Cruz I, Santos JP, Waquil JM. Controle químico da lagarta-do-cartucho em milho. PAB. 1982;17(5):677-81.

44. Litvan I, Bhatia KP, Burn DJ, Goetz CG, Lang AE, McKeith I, et al. Movement Disorders Society Scientific Issues Committee report: SIC Task Force appraisal of clinical diagnostic criteria for Parkinsonian disorders. Mov Disord. 2003;18(5):467-86. http://dx.doi.org/10.1002/mds.10459. PMid:12722160.

45. Van Den Eeden SK, Tanner CM, Bernstein AL, Fross RD, Leimpeter A, Bloch DA, et al. Incidence of Parkinson's disease: variation by age, gender, and race/ethnicity. Am J Epidemiol. 2003;157(11):1015-22. http://dx.doi. org/10.1093/aje/kwg068. PMid:12777365.

46. Keyser RJ, Lesage S, Brice A, Carr J, Bardien S. Assessing the prevalence of PINK1 genetic variants in South African patients diagnosed with early- and late-onset Parkinson's disease. Biochem Biophys Res Commun. 2010;398(1):125-9. http://dx.doi.org/10.1016/j.bbrc.2010.06.049. PMid:20558144.

47. Zhang BR, Hu ZX, Yin XZ, Cai M, Zhao GH, Liu ZR, et al. Mutation analysis of parkin and PINK1 genes in early-onset Parkinson's disease in China. Neurosci Lett. 2010;477(1):19-22. http://dx.doi.org/10.1016/j. neulet.2010.04.026. PMid:20399249.

48. Gershanik OS. Trauma and Parkinson's disease. Handb Clin Neurol. 2007;84:487-99. http://dx.doi. org/10.1016/S0072-9752(07)84057-7. PMid:18808966.

49. Gralewicz S, Dyzma M. Organic solvents and the dopaminergic system. Int J Occup Med Environ Health. 2005;18(2):103-13. PMid:16201201.

50. Lock EA, Zhang J, Checkoway H. Solvents and Parkinson disease: a systematic review of toxicological and epidemiological evidence. Toxicol Appl Pharmacol. 2013;266(3):345-55. http://dx.doi.org/10.1016/j. taap.2012.11.016. PMid:23220449.

51. Ritz B, Lee PC, Hansen J, Lassen CF, Ketzel M, Sorensen M, et al. Traffic-related air pollution and Parkinson's disease in Denmark: a case-control study. Environ Health Perspect. 2016;124(3):351-6. http://dx.doi. org/10.1289/ehp.1409313. PMid:26151951.

52. Lima EP, Paiva MH, Araujo AP, Silva EV, Silva UM, Oliveira LN, et al. Insecticide resistance in Aedes aegypti populations from Ceara, Brazil. Parasit Vectors. 2011;4(1):5. http://dx.doi.org/10.1186/1756-3305-4-5. PMid:21226942.

53. van den Berg H, Zaim M, Yadav RS, Soares A, Ameneshewa B, Mnzava A, et al. Global trends in the use of insecticides to control vector-borne diseases. Environ Health Perspect. 2012;120(4):577-82. http://dx.doi. org/10.1289/ehp.1104340. PMid:22251458.

54. Kessler R. Urban gardening: managing the risks of contaminated soil. Environ Health Perspect. 2013;121(1112):A326-33. http://dx.doi.org/10.1289/ehp.121-A326. PMid:24284011.

55. Wang A, Cockburn M, Ly TT, Bronstein JM, Ritz B. The association between ambient exposure to organophosphates and Parkinson's disease risk. Occup Environ Med. 2014;71(4):275-81. http://dx.doi. org/10.1136/oemed-2013-101394. PMid:24436061. 
56. Macoris MD. Avaliação do nível de suscetibilidade de linhagens de Aedes aegypti (Díptera: Culicidae) aos inseticidas utilizados para seu controle [dissertação]. Botucatu: Faculdade de Medicina, Universidade Estadual Paulista; 2002.

57. Franklin $\mathrm{HMOH}$, Peixoto TMAG. Níveis sanguíneos de $\mathrm{HCH}$ em guardas da Sucam sob alto contato como produto. In: Anais do X Encontro Nacional de Analistas de Resíduos de Pesticidas; 1986; São Paulo. São Paulo: Instituto Adolfo Lutz; 1986. p. 111-5. Relatório.

58. Mendes R. Hexaclorociclohexano $(\mathrm{HCH})$ e a Saúde Humana: síntese do estágio atual do conhecimento e identificação das principais questões controversas [Internet]. Brasília: Ministério da Saúde; 2001. Relatório técnico solicitado pelo Departamento de Ciência e Tecnologia em Saúde/Ministério da Saúde [cited 2013 Sept 15]. Available from: http://www.saude.sp.gov.br/resources/cve-centro-de-vigilancia-epidemiologica/ areas-de-vigilancia/doencas-ocasionadas-pelo-meio-ambiente/doc/2001 hexaclorocicloexano.pdf

59. Shahgholi L, De Jesus S, Wu SS, Pei Q, Hassan A, Armstrong MJ, et al. Hospitalization and rehospitalization in Parkinson disease patients: data from the National Parkinson Foundation Centers of Excellence. PLoS One. 2017;12(7):e0180425. http://dx.doi.org/10.1371/journal.pone.0180425. PMid:28683150.

60. Haaxma CA, Bloem BR, Borm GF, Oyen WJ, Leenders KL, Eshuis S, et al. Gender differences in Parkinson's disease. J Neurol Neurosurg Psychiatry. 2007;78(8):819-24. http://dx.doi.org/10.1136/jnnp.2006.103788. PMid:17098842.

61. Braga M, Pederzoli M, Antonini A, Beretta F, Crespi V. Reasons for hospitalization in Parkinson's disease: a case-control study. Parkinsonism Relat Disord. 2014;20(5):488-92. http://dx.doi.org/10.1016/j. parkreldis.2014.01.022. PMid:24582073.

62. Barreto SM, Giatti L, Kalache A. Gender inequalities in health among older Brazilian adults. Rev Panam Salud Publica. 2004;16(2):110-7. http://dx.doi.org/10.1590/S1020-49892004000800006. PMid:15357936.

63. Instituto Brasileiro do Meio Ambiente e dos Recursos Naturais Renováveis. Relatórios de comercialização de agrotóxicos [Internet]. 2016 [citado em 2020 Abril 19]. Disponível em: http://www.ibama.gov.br/ agrotoxicos/relatorios-de-comercializacao-de-agrotoxicos.

64. Frank C, Pari G, Rossiter JP. Approach to diagnosis of Parkinson's disease. Can Fam Physician. 2006;52(7):8628. PMid:16893149.

65. Almeida VES, Friedrich K, Tygel AF, Melgarejo L, Carneiro FF. Uso de sementes geneticamente modificadas e agrotóxicos no Brasil: cultivando perigos. Cien Saude Colet. 2017;22(10):3333-9. http://dx.doi. org/10.1590/1413-812320172210.17112017.

66. BøhnT, Millstone E. The introduction of thousands of tonnes of glyphosate in the food chain: an evaluation of glyphosate tolerant soybeans. Foods. 2019 dez;8(12):669. http://dx.doi.org/10.3390/foods8120669. PMid:31835834. 